\title{
On-pump beating-heart coronary artery bypass grafting after acute myocardial infarction has lower mortality and morbidity
}

Ken Miyahara, MD, Akio Matsuura, MD, Haruki Takemura, MD, Shunei Saito, MD, Sadanari Sawaki, MD, Teruaki Yoshioka, MD, and Hideki Ito, MD

Earn CME credits at http:// cme.ctsnetjournals.org
From the Division of Cardiovascular Surgery, Aichi Cardiovascular and Respiratory Center, Ichinomiya, Aichi, Japan.

Received for publication June 21, 2007; revisions received Sept 9, 2007; accepted for publication Oct 4, 2007

Address for reprints: Ken Miyahara, MD, Division of Cardiovascular Surgery, Aichi Cardiovascular and Respiratory Center. 2135 Kariyasuga, Yamato-cho, Ichinomiya, Aichi, 491-0934, Japan (E-mail: medical. miyahara@nifty.com).

J Thorac Cardiovasc Surg 2008;135:521-6 $0022-5223 / \$ 34.00$

Copyright $\odot 2008$ by The American Association for Thoracic Surgery

doi:10.1016/j.jtcvs.2007.10.006
Objective: The mortality of conventional coronary artery bypass grafting after acute myocardial infarction remains high. This study compared the clinical outcomes of patients undergoing conventional and on-pump beating-heart coronary artery bypass grafting and evaluated the efficacy of an on-pump beating-heart technique for the surgical treatment of these critically ill patients.

Methods: Between January 1999 and March 2005, 61 patients underwent emergency coronary artery bypass grafting for acute myocardial infarction. In the first 23 patients, the conventional cardioplegic method was performed. In the most recent 38 patients, the on-pump beating-heart procedure was used without cardioplegic arrest.

Results: A significant reduction occurred in the observed mortality between the conventional and on-pump beating groups $(21.7 \%$ vs $2.6 \%, P=.04)$, despite a higher predicted mortality risk calculated by using EuroSCORE $(9.0 \pm 1.6$ vs $9.6 \pm 1.6$, $P=.048)$ and a greater use of a preoperative intra-aortic balloon pump (43.5\% vs $78.9 \%, P=.005)$. On-pump beating-heart patients received fewer bypass grafts than conventional patients $(2.0$ vs $2.9, P=.001)$, but the internal thoracic artery was used more often in on-pump beating-heart patients $(P=.014)$. Three patients in the conventional coronary artery bypass grafting group required new insertion of an intra-aortic balloon pump, whereas no patients required this in the on-pump beating-heart group $(P=.220)$. Postoperative renal failure requiring hemodialysis occurred in 2 patients in the conventional coronary artery bypass grafting group but in no patients in the on-pump beating-heart group $(P=.138)$.

Conclusions: On-pump beating-heart coronary artery bypass grafting is the preferred method of emergency myocardial revascularization for patients with acute myocardial infarction who might tolerate cardioplegic arrest poorly. It has lower postoperative mortality and morbidity than conventional coronary artery bypass grafting.

$\mathrm{F}$ ibrinolytic therapy, percutaneous coronary intervention (PCI), or both is the preferred first-line therapy for acute myocardial infarction (AMI). ${ }^{1}$ Coronary artery bypass grafting $(\mathrm{CABG})$ in the presence of or immediately after AMI is controversial because the mortality from emergency CABG for AMI remains high. $^{2-5}$ However, we sometimes encounter selected patients requiring emergency surgical revascularization. Despite recent improvements in myocardial preservation techniques and the use of cardiac-assist devices, such as an intra-aortic balloon pump (IABP), the technique of aortic crossclamping and cardioplegic arrest (conventional $\mathrm{CABG}$ ) might induce myocardial and systemic organ damage during this critical situation.

To reduce the damaging effect of cardiac arrest and the mortality rate, we adopted the technique of on-pump beating-heart CABG. In this study we compared the clinical outcomes and laboratory data of patients undergoing conventional and on-pump beating-heart CABG and evaluated the efficacy of the on-pump beating-heart technique for the surgical treatment of AMI. 

Abbreviations and Acronyms
AMI = acute myocardial infarction
$\mathrm{CABG}=$ coronary artery bypass grafting
$\mathrm{CK}-\mathrm{MB}=$ creatinine kinase myocardial band
$\mathrm{CPB}=$ cardiopulmonary bypass
$\mathrm{IABP}=$ intra-aortic balloon pump
PCI = percutaneous coronary intervention

\section{Patients and Methods}

Between January 1999 and March 2005, 763 patients underwent isolated $\mathrm{CABG}$ at our institution. Of these patients, 61 (8\%) underwent emergency operations for AMI. We reviewed these 61 consecutive patients. In 23 patients seen from 1999 through November 2002, conventional CABG was performed on the arrested heart. The most recent 38 patients, treated between December 2002 and March 2005, underwent on-pump beating-heart CABG without cardioplegic arrest.

The diagnosis of AMI was based on clinical criteria, including electrocardiographic evidence (Q waves and ST-segment elevation) and characteristic increase in serum myocardial enzyme levels (creatine phosphokinase). All patients underwent emergency coronary angiography performed preoperatively by a cardiologist. Indications for emergency $\mathrm{CABG}$ included the following: patients with a contraindication for thrombolytic therapy, patients with coronary lesions unsuitable for primary PCI (including left main, complicated, and multiple lesions), and cardiogenic shock defined as a systolic blood pressure of less than $80 \mathrm{~mm} \mathrm{Hg}$ with or without IABP and pressor support, as well as clinical signs of hypoperfusion. The criteria for preoperative insertion of an IABP were as follows: cardiogenic shock or refractory ventricular failure, hemodynamic instability with or without catecholamines, unstable refractory angina, intractable ventricular arrhythmia, and a critical left main stenosis $(\geq 70 \%)$. Excluded from the analysis were patients who underwent surgical intervention for the mechanical complications of AMI (ventricular septum rupture, ruptured papillary muscle, or ventricular rupture), as well as patients who required additional procedures, such as left ventricular aneurysm or valve repair.

\section{Surgical Techniques}

Conventional CABG. A standardized anesthetic protocol was used in all patients. All operations were performed through a median sternotomy. Conduits were harvested and prepared, and the patients were heparinized with an initial dose of $300 \mathrm{IU} / \mathrm{kg}$ heparin to achieve a target activated clotting time of greater than 450 seconds. Cardiopulmonary bypass (CPB) was established by means of aortic cannulation and bicaval venous drainage. The left ventricle was consistently vented through the right superior pulmonary vein.

The standard CPB circuit incorporated a roller pump and a hollow-fiber membrane oxygenator. The extracorporeal circuit was primed with $1000 \mathrm{~mL}$ of Hartmann solution, $150 \mathrm{~mL}$ of mannitol, $20 \mathrm{~mL}$ of sodium bicarbonate, and $4000 \mathrm{IU}$ of heparin. The nonpulsatile flow was adjusted to between 2.0 and $2.5 \mathrm{~L} \cdot \mathrm{min}^{-1}$. $\mathrm{m}^{-2}$, and the blood pressure was maintained between 50 and $70 \mathrm{~mm} \mathrm{Hg}$. The systemic temperature was kept between $34^{\circ} \mathrm{C}$ and $36^{\circ} \mathrm{C}$.
The aorta was crossclamped, and myocardial protection was achieved with intermittent antegrade and retrograde tepid blood cardioplegia. The cardioplegic solution and delivery were the same as described by Caputo and colleagues. ${ }^{6}$ After the induction of ischemic arrest with dose $1(300 \mathrm{~mL} / \mathrm{min}$ blood for 2 minutes, $20 \mathrm{mEq} /$ $\mathrm{L}[\mathrm{K}]$, and $5 \mathrm{mEq} / \mathrm{L}[\mathrm{Mg}]$ ), subsequent doses were administered every 20 minutes. The distal anastomoses were constructed first with running sutures of 7-0 polypropylene, and the proximal anastomoses were connected to the ascending aorta with 6-0 polypropylene sutures during a single crossclamp period. After the patient was weaned from CPB and decannulated, the heparin was reversed.

On-pump beating-heart CABG. The anesthetic protocol, heparin dose, and $\mathrm{CPB}$ circuit were the same as with conventional CABG. CPB was established by means of aortic cannulation and insertion of a 2-stage venous cannula through the right atrial appendage. The operation was then continued on the assisted beating heart. The distal anastomoses were constructed before the proximal anastomoses. The left anterior descending coronary artery was revascularized first, followed by the circumflex and right coronary arteries. Regional myocardial immobilization was achieved with a suction stabilizer (Octopus, Medtronic, Minneapolis, Minn; Guidant Acrobat, Guidant, Indianapolis, Ind). An apical suction cardiac positioning device (Starfish, Medtronic) was used in revascularization of the circumflex and right coronary arteries to facilitate exposure. During construction of the anastomoses, target vessel hemostasis was obtained with intravascular shunts (Clearview, Medtronic) or temporary occlusion of the proximal coronary artery. All distal anastomoses were made with running sutures of 7-0 polypropylene. The proximal anastomoses were created with 6-0 polypropylene sutures under a partial occlusion clamp or proximal anastomotic system (Heartstring, Guidant). A humidified carbon dioxide blower was used for better visualization. After weaning from CPB and decannulation, the heparin was reversed.

\section{Statistical Analysis}

The results for categorical variables are expressed as numbers (percentages). Continuous variables are presented as the mean \pm standard deviation. The Fisher exact test or the $\chi^{2}$ test was used to compare categorical variables. The continuous variables were compared by using the Student $t$ test.

\section{Results}

The respective number of patients with AMI hospitalized, the number of patients with AMI with PCI, the number of CABG procedures, and the number of cases thrombolytic or medical therapy used during the same period were 422, 371, 23, and 28 in the conventional CABG group and 415, 353, 38, and 24 in the on-pump beating-heart CABG group. In both groups surgical patients constituted $5.5 \%$ versus $8.4 \%$ of all patients with AMI hospitalized during the same time period, respectively $(P=.06)$.

The demographic and preoperative patient characteristics of the 2 groups are presented in Table 1 . No significant differences were observed between the groups in terms of age, sex, comorbidities, number of diseased vessels, AMI location, left main trunk lesion, shock, creatinine, and creatinine kinase myocardial band (CK-MB) values. All patients in the 
TABLE 1. Patient characteristics

\begin{tabular}{|c|c|c|c|}
\hline $\begin{array}{c}\text { Preoperative } \\
\text { variables }\end{array}$ & $\begin{array}{c}\text { Conventional } \\
\text { CABG } \\
(n=23)\end{array}$ & $\begin{array}{c}\text { On-pump } \\
\text { beating-heart } \\
\text { CABG }(n=38)\end{array}$ & $\begin{array}{c}P \\
\text { value }\end{array}$ \\
\hline Age, y & $65.4 \pm 9.7$ & $65.8 \pm 10.3$ & .887 \\
\hline Male sex & 18 & 28 & .688 \\
\hline Hypertension & 6 & 17 & .180 \\
\hline Diabetes mellitus & 6 & 16 & .254 \\
\hline Hyperlipidemia & 2 & 5 & .466 \\
\hline Smoking & 14 & 17 & .184 \\
\hline $\begin{array}{l}\text { Family history of coronary } \\
\text { disease }\end{array}$ & 5 & 7 & .580 \\
\hline No. of diseased vessels & $3.2 \pm 1.6$ & $2.6 \pm 1.2$ & .070 \\
\hline \multicolumn{4}{|l|}{ AMI location } \\
\hline Anterior & 14 & 25 & .700 \\
\hline Inferior & 6 & 9 & .533 \\
\hline Anterolateral (LMT) & 3 & 4 & .534 \\
\hline LMT & 11 & 15 & .523 \\
\hline Shock & 3 & 3 & .410 \\
\hline EuroSCORE & $9.0 \pm 1.6$ & $9.9 \pm 1.6$ & .048 \\
\hline Preoperative IABP & 10 & 30 & .005 \\
\hline Serum creatinine $(\mathrm{mg} / \mathrm{dL})$ & $0.92 \pm 0.36$ & $0.94 \pm 0.40$ & .896 \\
\hline CK-MB (mg/dL) & $62.7 \pm 73.0$ & $118.6 \pm 216.0$ & .469 \\
\hline $\begin{array}{l}\text { Time interval from } \\
\text { onset to CABG (h) }\end{array}$ & $27.0 \pm 22.0$ & $18.3 \pm 17.1$ & .100 \\
\hline
\end{tabular}

Continuous variables are presented as means \pm standard deviation. $C A B G$, Coronary artery bypass grafting; $A M I$, acute myocardial infraction; $L M T$, left main trunk; $I A B P$, intra-aortic balloon pump; $C K-M B$, creatine kinase myocardial band.

conventional group and $36(94.7 \%)$ of 38 patients in the onpump beating-heart group had multivessel disease. Therefore only 2 patients had single-vessel disease: one was in cardiogenic shock, and the other had a long left anterior descending coronary artery lesion that was not suitable for PCI.

The predicted mortality risk calculated by using Euro$\mathrm{SCORE}^{7}$ was significantly higher in the on-pump beatingheart $\mathrm{CABG}$ group than in the conventional $\mathrm{CABG}$ group $(9.9 \pm 1.6$ vs $9.0 \pm 1.6, P=.048)$. The preoperative use of IABP was also greater in the on-pump beating-heart CABG group $(78.9 \%$ vs $43.5 \%, P=.005)$. These data mean that patients undergoing on-pump beating-heart CABG were in more critical states than the patients undergoing conventional CABG.

The time interval from the onset of AMI to CABG was similar $(27.0 \pm 22.0$ vs $18.3 \pm 17.1$ hours, $P=.100)$. Table 2 lists the breakdown of the specific timing of CABG after AMI and mortality. No significant difference was observed between the groups.

All patients in both groups had ST-segment elevation. Nineteen of 23 patients in the conventional CABG group and 29 of 38 patients in the on-pump beating-heart CABG group had a $\mathrm{Q}$ wave $(82.6 \%$ vs $76.3 \%, P=.404)$.

Table 3 shows the intraoperative variables of the patients. The CPB time was significantly longer in the conventional
TABLE 2. Timing of CABG after AMI and mortality

\begin{tabular}{lcc}
\hline Conventional & On-pump \\
CABG (n = 23) & $\begin{array}{c}\text { beating-heart } \\
\text { CABG (n= 38) }\end{array}$ \\
\hline $3-6 \mathrm{~h}$ & $2(1)$ & $4(1)$ \\
$7-24 \mathrm{~h}$ & $14(3)$ & 25 \\
$25-72 \mathrm{~h}$ & $7(1)$ & 9 \\
\hline
\end{tabular}

Mortality is shown in parentheses. $C A B G$, Coronary artery bypass grafting; $A M I$, acute myocardial infarction.

CABG group than in the on-pump beating-heart CABG group (185 \pm 49 vs $126 \pm 36$ minutes, $P=.0001)$. The on-pump beating-heart $\mathrm{CABG}$ group underwent fewer bypass grafts per patient $(2.0 \pm 0.7$ vs $2.9 \pm 0.9, P=.001)$. We tried to bypass not only the vessel responsible for AMI but also the target vessels that could be bypassed. Left anterior descending coronary artery bypass was performed, except in one case in the on-pump beating-heart group. The internal thoracic artery was used more often in patients undergoing on-pump beating-heart CABG $(39.1 \%$ vs $71.1 \%, P=$ .014). Three patients in the conventional CABG group required new insertion of an IABP, whereas no patients required this in the on-pump beating-heart $\mathrm{CABG}$ group, although the difference was not statistically significant $(P=.220)$.

The postoperative patient findings and early outcome data are presented in Table 4 . The postoperative maximum CK$\mathrm{MB}$ values in the conventional $\mathrm{CABG}$ group were higher than those in the on-pump beating-heart CABG group (188 \pm 359 vs $106 \pm 86 \mathrm{IU} / \mathrm{L}$ ), but the difference was not statistically significant. The duration of inotropic support, duration of IABP use, time to extubation, duration of intensive care unit stay, and length of hospital stay were lower in the onpump beating-heart CABG group, but these differences did not reach significance. All surviving patients underwent early postoperative coronary angiography during their hospital stays. Graft patency in the on-pump beating-heart CABG

\section{TABLE 3. Intraoperative variables}

\begin{tabular}{lccr}
\hline $\begin{array}{c}\text { Intraoperative } \\
\text { variables }\end{array}$ & $\begin{array}{c}\text { Conventional } \\
\text { CABG (n= 23) }\end{array}$ & $\begin{array}{c}\text { On-pump } \\
\text { beating-heart } \\
\text { CABG (n = 38) }\end{array}$ & $\begin{array}{c}\boldsymbol{P} \\
\text { value }\end{array}$ \\
\hline $\begin{array}{l}\text { CPB time (min) } \\
\begin{array}{c}\text { Aortic crossclamp } \\
\text { time (min) }\end{array}\end{array}$ & $\begin{array}{c}185 \pm 49 \\
92.8 \pm 28.6\end{array}$ & $126 \pm 36$ & .0001 \\
$\begin{array}{l}\text { No. of distal } \\
\text { anastomoses }\end{array}$ & $2.9 \pm 0.9$ & $2.0 \pm 0.7$ & .0001 \\
$\begin{array}{l}\text { ITA used } \\
\text { New IABP }\end{array}$ & 9 & 27 & .001 \\
\hline $\begin{array}{l}\text { Continuous variables are presented as means } \pm \text { standard deviation. } C A B G, \\
\text { Coronary artery bypass grafting; CPB, cardiopulmonary bypass; ITA, internal } \\
\text { thoracic artery; IABP, intra-aortic balloon pump. }\end{array}$ &
\end{tabular}


TABLE 4. Postoperative variables

\begin{tabular}{|c|c|c|c|}
\hline Postoperative variables & $\begin{array}{l}\text { Conventional } \\
\text { CABG }(n=23)\end{array}$ & $\begin{array}{c}\text { On-pump } \\
\text { beating-heart } \\
\text { CABG }(n=38)\end{array}$ & $\begin{array}{c}P \\
\text { value }\end{array}$ \\
\hline Maximum CK-MB (mg/dL) & $188 \pm 359$ & $106 \pm 86$ & .256 \\
\hline $\begin{array}{l}\text { Duration of inotropic } \\
\text { support (d) }\end{array}$ & $5.2 \pm 4.3$ & $6.1 \pm 4.1$ & .476 \\
\hline Duration of IABP use (d) & $3.3 \pm 2.3$ & $2.6 \pm 1.4$ & .269 \\
\hline Time to extubation (h) & $91.2 \pm 110.4$ & $79.2 \pm 86.4$ & .681 \\
\hline Duration of ICU stay (d) & $7.0 \pm 6.6$ & $6.0 \pm 3.0$ & .400 \\
\hline $\begin{array}{l}\text { Length of hospital } \\
\text { stay (d) }\end{array}$ & $31.8 \pm 19.3$ & $29.8 \pm 21.0$ & .715 \\
\hline Graft patency (\%) & 95.7 & 98.5 & .090 \\
\hline $\begin{array}{r}\text { Postoperative renal } \\
\text { failure }(\text { Cre } 2.0<\text { ) }\end{array}$ & 2 & 0 & .138 \\
\hline $\begin{array}{l}\text { Neurophysiologic } \\
\text { complications }\end{array}$ & 0 & 0 & 1.000 \\
\hline Hospital mortality (\%) & 21.7 & 2.6 & .046 \\
\hline
\end{tabular}

Continuous variables are presented as means \pm standard deviation. $C A B G$, Coronary artery bypass grafting; $C K-M B$, creatine kinase myocardial band; $I A B P$, intra-aortic balloon pump; $I C U$, intensive care unit; $\mathrm{Cre}$, serum creatinine $(\mathrm{mg} / \mathrm{dL})$.

group was similar to that of the conventional $\mathrm{CABG}$ group (98.5\% vs $95.7 \%$ ). Postoperative renal failure occurred in 2 patients in the conventional CABG group but in no patients in the on-pump beating-heart group $(P=.138)$. These 2 patients required postoperative hemodialysis. No neurophysiologic complications developed in either group. Five hospital deaths occurred in the conventional CABG group (21.7\%), whereas only $1(2.6 \%)$ patient died in the on-pump CABG group. The hospital mortality rate was remarkably lower in the on-pump beating-heart CABG group $(P=.04)$. Of the 3 patients with preoperative cardiogenic shock in each group, 2 patients died in the conventional group, whereas 1 patient died in the on-pump beating-heart group. The cause of death in all patients was low-output syndrome.

\section{Discussion}

With improved myocardial protection, anesthesia, and surgical techniques, CABG is generally safe and efficient, although high mortality and morbidity are still documented in emergency conventional CABG after AMI. ${ }^{2-5}$ The reasons for this poor result include both the patients' poor preoperative status, including cardiogenic shock ${ }^{5}$ or organ failure, and myocardial damage after cardioplegic arrest.

As an alternative to conventional CABG for patients with AMI, we recently adopted on-pump beating-heart CABG. On-pump beating-heart $\mathrm{CABG}$ is an attractive technique that keeps a heartbeat with the aid of CPB but without aortic crossclamping or cardioplegic arrest. Izumi and associates ${ }^{8}$ demonstrated that on-pump beating-heart CABG reduces the mortality of patients with AMI and decreases the release of CK-MB compared with conventional CABG. The avoidance of cardioplegic arrest can eliminate intraoperative global myocardial ischemia, which might contribute to myocardial protection. ${ }^{9}$ The beating heart can preserve native coronary blood flow, which might reduce myocardial injury. ${ }^{10}$ Historically, Sweeney and Frazier ${ }^{11}$ demonstrated on-pump beating-heart bypass as an interesting tradeoff, using biventricular assist devices and the $\beta$-blocker esmolol during coronary revascularization in severely ill patients. Perrault and colleagues ${ }^{9}$ described on-pump beating-heart coronary operations as an acceptable tradeoff between conventional CABG and off-pump coronary artery bypass in high-risk patients. Experimentally, it has been demonstrated that maintaining the heartbeat results in minimal myocardial edema and better left ventricular function. ${ }^{12}$

Another advantage of on-pump beating-heart surgery is that it allows optimal exposure of the coronary arteries. ${ }^{13}$ This avoids extreme upward retraction of the heart, especially during revascularization of the circumflex branch ${ }^{14}$ which might contribute to better myocardial protection. ${ }^{14}$

Theoretically, off-pump CABG seems to be an ideal procedure. Several studies, ${ }^{15-20}$ including randomized controlled studies ${ }^{18,19}$ and a propensity score analysis, ${ }^{20}$ have compared off-pump and conventional CABG and revealed that off-pump CABG in selected patients is safe and has a short-term cardiac outcome comparable with that of conventional CABG. However, most of these studies excluded emergency patients with AMI, left main coronary artery stenosis, reoperation, or major left ventricular hypertrophy or dilatation. Few reports are available on the outcome of offpump CABG for AMI. Locker and coworkers ${ }^{21}$ demonstrated that emergency off-pump CABG for AMI results in lower mortality compared with conventional CABG (5\% vs $24 \%$ ); however, the late mortality increased, and the longterm results of patients operated on without CPB were no better than the results of those operated on with $\mathrm{CPB}$, which might have been related to the incomplete revascularization or inferior patency rate of anastomoses performed on the beating heart. Others have also reported an inferior graft patency rate or recurrent symptoms compared with the conventional technique. ${ }^{16,19}$

Note that off-pump CABG is essentially associated with an acute conversion risk, which causes death and serious complications in the hospital. ${ }^{22-27}$ In $2004,4.5 \%$ of patients in Japan were converted from off-pump coronary artery bypass to on-pump bypass in isolated, primary, emergency $\mathrm{CABG}$, and their hospital mortality reached $23.8 \% .^{22}$ The conversion risks are difficult to quantify precisely. ${ }^{25}$ Suggested predictors of conversion have included previous CABG, congestive heart failure, a surgeon with insufficient experience, a low ejection fraction, and recent myocardial infarction. ${ }^{23,26,28}$

We do not believe that off-pump CABG should be used in all patients with AMI. An appropriate circulatory support system should be applied to improve their hemodynamic 
status $^{5}$ and compensate visceral organ perfusion because most of the patients are hemodynamically unstable and have poor perfusion of their visceral organs. CPB has a preventive role when cardiac arrest or severe hemodynamic alterations occur during surgical intervention. ${ }^{13}$ Vassiliades and associates ${ }^{26}$ suggested considering the on-pump beating-heart technique to prevent catastrophic sudden hemodynamic collapse in CABG. CPB can unload the heart and guarantee adequate organ perfusion. ${ }^{10}$ In our experience we found no difference in the incidence of renal failure, although on-pump beating-heart CABG seems to cause significantly less renal dysfunction. ${ }^{13}$

The drawback of the on-pump beating-heart CABG technique is the cost increase caused by both perfusion costs and the cost of disposable devices. Another disadvantage is that it requires manipulation of the ascending aorta for inflow cannula insertion, which might cause atheromatous macroemboli. $^{29}$ We must consider femoral cannulation when possible atheromatous changes of the ascending aorta exist.

A worrisome finding in our study was the less-complete revascularization in our on-pump beating-heart patients. The reason for this difference might be that the number of the grafts was due to the surgeon's preference at the time of surgical intervention. Although incomplete revascularization did not increase the early risk, it might affect the longterm results of revascularization. ${ }^{16,21}$ Therefore the patients require careful follow-up as outpatients.

\section{Limitations}

Our study has several limitations. First, this study was a clinical review of patients who underwent conventional and onpump beating-heart primary CABG. Patients were not assigned to either group randomly, and a historical difference existed between the 2 groups. Second, the number of patients in each group was small. Further studies are necessary and expected.

\section{Conclusions}

Our experience suggests that on-pump beating-heart CABG is the preferable method of emergency myocardial revascularization for patients with AMI who might tolerate cardioplegic arrest poorly. It has a lower mortality and morbidity than conventional $\mathrm{CABG}$.

\section{References}

1. Eagle KA, Guyton RA, Davidoff R, Edwards FH, Ewy GA, Gardner TJ, et al. ACC/AHA 2004 guideline update for coronary artery bypass graft surgery. American College of Cardiology; American Heart Association. Circulation. 2004;110:e340-437.

2. Wasvary H, Shannon F, Bassett J, O'Neill W. Timing of coronary artery bypass grafting after acute myocardial infarction. Am Surg. 1997;63: 710-5.

3. Kaul TK, Fields BL, Riggins SL, Dacumos GC, Wyatt DA, Jones CR. Coronary artery bypass grafting within 30 days of an acute myocardial infarction. Ann Thorac Surg. 1995;59:1169-76.
4. Quigley RL, Milano CA, Smith LR, White WD, Rankin JS, Glower DD. Prognosis and management of anterolateral myocardial infarction in patients with severe left main disease and cardiogenic shock. The left main shock syndrome. Circulation. 1993;88(suppl):II65-70.

5. Yamagishi I, Sakurada T, Abe T. Emergency coronary artery bypass grafting after acute myocardial infarction. What influences early postoperative mortality? Ann Thorac Cardiovasc Surg. 1998;4:28-33.

6. Caputo M, Bryan AJ, Calafiore AM, Suleiman MS, Angelini GD. Intermittent antegrade hyperkalaemic warm blood cardioplegia supplemented with magnesium prevents myocardial substrate derangement in patients undergoing coronary artery bypass surgery. Eur J Cardiothorac Surg. 1998;14:596-601.

7. Nashef SA, Roques F, Michel P, Gauducheau E, Lemeshow S, Salamon R. European System for Cardiac Operative Risk Evaluation (EuroSCORE). Eur J Cardiothorac Surg. 1999;16:9-13.

8. Izumi Y, Magishi K, Ishikawa N, Kimura F. On-pump beating-heart coronary artery bypass grafting for acute myocardial infarction. Ann Thorac Surg. 2006;81:573-6.

9. Perrault LP, Menasché P, Peynet J, Faris B, Bel A, de Chaumaray T, et al. On-pump, beating-heart coronary artery operations in high-risk patients: an acceptable trade-off? Ann Thorac Surg. 1997;64: 1368-73.

10. Rastan AJ, Bittner HB, Gummert JF, Walther T, Schewick CV, Girdauskas E, et al. On-pump beating heart versus off-pump coronary artery bypass surgery-evidence of pump-induced myocardial injury. Eur J Cardiothorac Surg. 2005;27:1057-64.

11. Sweeney MS, Frazier OH. Device-supported myocardial revascularization: safe help for sick hearts. Ann Thorac Surg. 1992;54:1065-70.

12. Mehlhorn U, Allen SJ, Adams DL, Davis KL, Gogola GR, Warters RD. Cardiac surgical conditions induced by beta-blockade: effect on myocardial fluid balance. Ann Thorac Surg. 1996;62:143-50.

13. Prifti E, Bonacchi M, Frati G, Giunti G, Proietti P, Leacche M, et al. Beating heart myocardial revascularization on extracorporeal circulation in patients with end-stage coronary artery disease. Cardiovasc Surg. 2001;9:608-14.

14. Borowski A, Korb H. Myocardial infarction in coronary bypass surgery using on-pump, beating heart technique with pressure- and volumecontrolled coronary perfusion. J Card Surg. 2002;17:272-8.

15. Bull DA, Neumayer LA, Stringham JC, Meldrum P, Affleck DG, Karwande SV. Coronary artery bypass grafting with cardiopulmonary bypass versus off-pump cardiopulmonary bypass grafting: does eliminating the pump reduce morbidity and cost? Ann Thorac Surg. 2001; 71:170-5.

16. Gundry SR, Romano MA, Shattuck OH, Razzouk AJ, Bailey LL. Seven-year follow-up of coronary artery bypasses performed with and without cardiopulmonary bypass. $J$ Thorac Cardiovasc Surg. 1998;115:1273-8.

17. Mack M, Bachand D, Acuff T, Edgerton J, Prince S, Dewey T, et al. Improved outcomes in coronary artery bypass grafting with beatingheart techniques. J Thorac Cardiovasc Surg. 2002;124:598-607.

18. van Dijk D, Nierich AP, Jansen EW, Nathoe HM, Suyker WJ, Diephuis JC, et al. Early outcome after off-pump versus on-pump coronary bypass surgery: results from a randomized study. Circulation. 2001;104:1761-6.

19. Khan NE, De Souza A, Mister R, Flather M, Clague J, Davies S, et al. A randomized comparison of off-pump and on-pump multivessel coronary-artery bypass surgery. $N$ Engl J Med. 2004;350:21-8.

20. Sabik JF, Gillinov AM, Blackstone EH, Vacha C, Houghtaling PL, Navia J, et al. Does off-pump coronary surgery reduce morbidity and mortality? J Thorac Cardiovasc Surg. 2002;124:698-707.

21. Locker C, Shapira I, Paz Y, Kramer A, Gurevitch J, Matsa M, et al. Emergency myocardial revascularization for acute myocardial infarction: survival benefits of avoiding cardiopulmonary bypass. Eur J Cardiothorac Surg. 2000;17:234-8.

22. Kazui T, Osada H, Fujita H. Thoracic and Cardiovascular Surgery in Japan during 2004. Annual report by the Japanese Association for Thoracic Surgery. Jpn J Thorac Cardiovasc Surg. 2006;54: 363-86.

23. Edgerton JR, Dewey TM, Magee MJ, Herbert MA, Prince SL, Jones KK, et al. Conversion in off-pump coronary artery bypass 
grafting: an analysis of predictors and outcomes. Ann Thorac Surg. 2003;76:1138-43

24. Légaré JF, Buth KJ, Hirsch GM. Conversion to on pump from OPCAB is associated with increased mortality: results from a randomized controlled trial. Eur J Cardiothorac Surg. 2005;27:296-301.

25. Reeves BC, Ascione R, Caputo M, Angelini GD. Morbidity and mortality following acute conversion from off-pump to on-pump coronary surgery. Eur J Cardiothorac Surg. 2006;29:941-7.

26. Vassiliades TA Jr, Nielsen JL, Lonquist JL. Hemodynamic collapse during off-pump coronary artery bypass grafting. Ann Thorac Surg. 2002;73:1874-9.
27. Ashraf $\mathrm{O}$. Is off-pump therapy really the right choice in urgent coronary grafting? J Thorac Cardiovasc Surg. 2006;132:211-2.

28. Soltoski P, Salerno T, Levinsky L, Schmid S, Hasnain S, Diesfeld T, et al. Conversion to cardiopulmonary bypass in off-pump coronary artery bypass grafting: its effect on outcome. J Card Surg. 1998;13: 328-34.

29. Hartman GS, Yao FS, Bruefach M 3rd, Barbut D, Peterson JC, Purcell MH, et al. Severity of aortic atheromatous disease diagnosed by transesophageal echocardiography predicts stroke and other outcomes associated coronary artery surgery: a prospective study. Anesth Analg. 1996;83:701-8.

Access to The Journal of Thoracic and Cardiovascular Surgery Online is reserved for print subscribers!

Full-text access to The Journal of Thoracic and Cardiovascular Surgery Online is available for all print subscribers. To activate your individual online subscription, please visit The Journal of Thoracic and Cardiovascular Surgery Online, point your browser to http://www.mosby.com/itcvs, follow the prompts to activate your online access, and follow the instructions. To activate your account, you will need your subscriber account number, which you can find on your mailing label (note: the number of digits in your subscriber account number varies from 6 to 10). See the example below in which the subscriber account number has been circled:

\section{Sample mailing label}

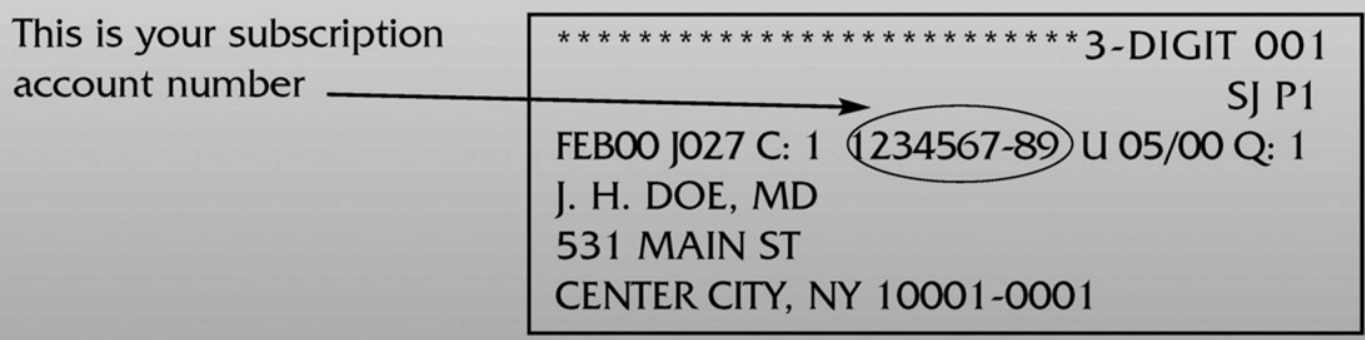

Personal subscriptions to The Journal of Thoracic and Cardiovascular Surgery Online are for individual use only and may not be transferred. Use of The Journal of Thoracic and Cardiovascular Surgery Online is subject to agreement to the terms and conditions as indicated online. 